\title{
UK Renal Registry 14th Annual Report: Appendix G UK Renal Registry Dataset Specification
}

This appendix is available on the UK Renal Registry website only. The current version of this document can be found under the downloads menu at www.renalreg.org.

\section{KARGER}

Fax +4161306 1234

E-Mail karger@karger.ch www.karger.com 